\title{
Historians and the centenary commemorations
}

Les historiens et le centenaire de la Grande Guerre

\section{Pat Thane}

\section{(2) OpenEdition}

\section{Journals}

Electronic version

URL: http://journals.openedition.org/rfcb/292

DOI: $10.4000 /$ rfcb.292

ISSN: 2429-4373

\section{Publisher}

CRECIB - Centre de recherche et d'études en civilisation britannique

\section{Printed version}

Date of publication: 15 January 2015

ISSN: 0248-9015

\section{Electronic reference}

Pat Thane, "Historians and the centenary commemorations », Revue Française de Civilisation Britannique [Online], XX-1 | 2015, Online since 01 May 2015, connection on 21 April 2019. URL : http:// journals.openedition.org/rfcb/292; DOI : 10.4000/rfcb.292

This text was automatically generated on 21 April 2019

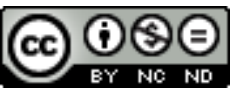

Revue française de civilisation britannique est mis à disposition selon les termes de la licence Creative Commons Attribution - Pas d'Utilisation Commerciale - Pas de Modification 4.0 International. 


\title{
Historians and the centenary commemorations
}

\author{
Les historiens et le centenaire de la Grande Guerre
}

\author{
Pat Thane
}

1 Perhaps because I am a Professor of Contemporary History I find that I am most curious about what exactly interests people now about World War 1 ? That is, people who are not professional historians. Or are many people indeed interested or just being told by the government, the press and television that they should be interested? It is hard to know, although there clearly is much popular interest in history in Britain, as suggested by the popularity of TV history series and historical novels; and the history of war seems to appeal to many people, though especially, I think, to men.

But why so much attention to this particular episode in history? What exactly is being celebrated, or commemorated (which it is also unclear), so extensively in the media and encouraged by the government- already, even before the anniversary of the start of the war in August 2014? Obviously we are honouring the many who fought and died, but we do that every year, on November 11th. This is Remembrance Day which officially commemorates British people who died and participated - as soldiers, sailors, nurses etcin all wars, but November 11th is the anniversary of the armistice on November 11 1918; that armistice gave birth to the idea of Remembrance Day in Britain which was first celebrated on that day in 1919 and has continued ever since; we commemorate by wearing poppies, introduced in Britain in 1921 ( the idea was brought here by a Frenchwoman, who adopted it from an American, Moira Michael, who first had the idea). The poppy is still very widely worn and symbolizes Remembrance because it evokes the fighting and the deaths in the poppy fields of Northern France in the spring of 1915. Our main Ceremony of Remembrance is held at the Cenotaph in Whitehall in London, which was built to commemorate World War 1 . So it is not a forgotten war, of which we need to be reminded. Perhaps it is because it is still so present in our lives and rituals that people are curious about why it happened and what were its results. Despite the distance in time and the fact that the last British veteran of the war died only about a year ago, many people still alive have grown up with the memories of their grandfathers and great- 
grandfathers who fought. My grandfather screamed in his sleep to the end of his life, with nightmares of his experiences in battle. And he had good memories of the prisoners he later guarded in Egypt and the presents they made him from old ammunition, some of which I still have along with his war medals. So the war that started a hundred years ago is not quite so distant or unknown to people today.

But these private memories do not explain what our government and media believe they are celebrating/commemorating. Perhaps it will be easier to understand if we can look at how different countries that were involved in the war are responding to the anniversary, since it was, after all, the first 'world' war, though it was not regularly called that in Britain until the next world war came around. More immediately it was called the 'Great' war, indeed 'the Great War for Civilization', and the 'war to end wars' (though of course it did not), and in what sense it was 'great' bears many interpretations.

The Guardian newspaper pointed out the other day that the German government has few plans to mark the anniversary. It is spending only about $4 \mathrm{~m}$ euros on events, whereas Britain and France are spending about $60 \mathrm{~m}$ each. No events are planned by the Federal government and Angela Merkel, it seems, has no plans to attend any events, though some of her Ministers will attend those in France. It is perhaps not surprising that the country that started the fighting and was defeated is more reluctant to remember than the countries that were on the winning side. But in Germany too the war is part of the national and personal histories. Some events are being organized at the local level including exhibitions about the local experience of war e.g., in Weimar there is an exhibition on Weimar in the war. A petroleum museum in lower Saxony is holding an exhibition on petroleum in the war. This is not so odd, given the importance of new resources and technologies- from aeroplanes to lethal gases and chemicals making munitions ever more explosive- in making the war as damaging as it was.

5 A German historian colleague tells me that there is plenty of public and press interest in the origins of the war, in particular in the extent of German responsibility for starting it. A recent book by a British historian, Christopher Clark's Sleepwalkers, which plays down German guilt, emphasizes that of Serbia and presents all the great powers as more or less 'sleepwalking' into a war much worse than they expected, has had a bigger impact in Germany than in Britain. Clarke recently gave a lecture to a packed hall in Berlin and his argument is quite widely appealing, I am told, though the issue of the extent of German guilt for the war is still being debated among historians and in the serious press.

6 Not surprisingly, nations are commemorating the war in ways that reflect the diverse ways it impacted on them: Germany divided and exercised over the extent of its guilt, but its government apparently keeping its distance from the debate over the extent of its responsibility for conflict with countries with which it is now partners in the EU.

7 In the US nothing seems to be happening so far, but they did not join the war until 1917. It will be interesting in 2017 to hear how/whether they commemorate their then President Woodrow Wilson, who played a big part in working for peace in the short run and, less successfully, in the longer run by initiating the League of Nations.

In Ireland there is a greater focus on the battle before during and after 1914-18 for independence from Britain, and there are more planned public commemorations of events related to that struggle, like the Easter Rising in Dublin of 1916 and its bloody suppression by the British, than of the war, despite the fact that very many Irishmen fought and died in the British army in the war. However, there is an Irish government 
website which commemorating them and listing the battles in which they fought, though no planned public remembrance.

There is much more public commemoration in Australia where the government is spending about $£ 50 \mathrm{~m}$ on events, and in New Zealand. The war has a special place in the national identities of both countries, who both fought with Britain alongside other colonies of the British Empire. Especially important in both countries is the memory of Gallipoli, the disastrous battle in the Dardanelles where over 7000 Australians and 2000 New Zealanders were killed. In both countries, Remembrance commemorations every year occur not only on November 11th, but on ANZAC day in late April, the date of Gallipoli. The sense of being betrayed and abandoned by Britain at Gallipoli increased the sense of national identity in both countries and of a desire for greater independence within the Empire, though not in their cases from the Empire. As the Australian official historian put it:' in those days Australia became fully conscious of itself as a nation'. This is what is important about the war for Australia and New Zealand and what they are remembering now.

10 I do not know what is happening in other former British colonies. India would be especially interesting. One million Indians served in the war and many thousands were killed or wounded. There was already an independence movement- for real independence from the British Empire- before the war and participation in the war strengthened both resentment against Britain and national confidence in India's capacity for independence. It also gained momentum from Woodrow Wilson making the right of all countries to selfdetermination central to the post-war peace negotiations. The Indian independence movement was stronger after the war and a persistent source of tension for Britain between the wars, leading in 1947 to independence after the next war (in which India, like other colonies, also fought alongside Britain, though some Indians opposed this). It would be interesting to know how the war is being remembered in India and in the other British colonies who fought.

11 It would be good to compare commemoration of the war in more countries. It seems so far that commemoration is very nationally based, with little focus on the alliances and collaborations across nations which were an important feature of the war. Perhaps this would evoke too many uncomfortable memories, of colonialism for some, of conflict within what is now a European Union for others, though for historians they deserve exploration.

12 Looking at responses in other countries returns me to wondering what exactly are we commemorating in Britain- apart from the men who fought, as we do every year? Here as elsewhere there are local events and events organized by specific interest groups: opponents of war are celebrating the conscientious objectors; women historians remembering the roles of women in the war. Museums and art galleries stage war-related exhibitions. The Imperial War Museum, which was developed during World War 1, to commemorate it even as it was in progress, is being refurbished and will reopen in July, ready for the anniversary of the opening of the war, with new First World War galleries which, among other things, will use modern technology to convey the wartime experiences of 8 million people. As its website states: 'The First World War was a turning point in world history. It claimed the lives of over 16 million people across the globe and had an impact on the lives of everyone'. It will be interesting to see when it opens how national, or international, is its approach. 
ar certainly did lead to change, nationally and internationally. Britain was on the winning side, but in important ways it emerged weaker from the war. The economy was still relatively strong, despite the war debt, but countries that had kept out of the war, wholly like Japan or partly like the US, benefitted from the absorption of Europe in war to increase their share of trade, while that of Britain declined; and the US took over from the City of London as the leading world financial centre. The war brought an end to two Empires- the Hapsburg and the Ottoman- and the revolution of 1917 transformed the Russian Empire. On the other hand, the Empires of Britain and France emerged bigger than ever from the peace negotiations .They divided up between them former German colonies in Africa and components of the former Ottoman Empire in the Middle East. But these were doubtful gains, for Britain anyway. Egypt, Iraq, above all Palestine, caused persistent problems and costs for Britain between the war, as did other restive colonies, above all India, challenging the existence of the Empire.

Internationally Britain was weaker after the war. At home it was also changed. The economy was weaker. The labour movement was stronger and more confident, following the unprecedented full-employment of wartime. From 1918 all adult men and most women over 30 had the vote for the first time. Britain at last came close to formal democracy, which some politicians found scary. Women had made other moves towards equality, including even joining the armed services for the first time, though not, of course, to fight. The country certainly was not revolutionized but it was permanently changed, as was much of the world by the war. For historians it is a fascinating, often baffling period. I'm still curious to know what others think about it.

The most appropriate role for historians in relation to the war is to do our best to inform people as accurately as possible about the events and the outcomes of the war. Unfortunately, so far, British TV is not helping, since it seems to prefer promoting controversial, if doubtful, interpretations of the war over more accurate ones. Perhaps this will change over the coming four years. We shall see.

\section{AUTHOR}

\section{PAT THANE}

King's College London 